\title{
EUROPEAN UNION AND LANGUAGE
}

\author{
Ahmet Kasumović ${ }^{1}$ \\ Institute for Human Rehabilitation, Tuzla, B\&H
}

Received: 02.08.2015

Accepted: 17.09.2015
Original scientific paper

UDC:81'244:061.1EU(049.5)

\begin{abstract}
There are many reasons for establishment of the European Union, but there are a lot of issues that European Union has to address continually and immediately, and there are even more issues, crucial for further profiling and survival of European Union, that have not been even considered yet. One of the unresolved and very important issues is its language. The dilemma is language (languages) of European Union and the question of fate of local (native) languages. Keywords: European Union, language, literature, communication, art
\end{abstract}

\section{RESEARCH}

The study included the future residents of the European Union and speakers present-official residents/ citizens of the Union, i.e. current residents of member-states of the Union, and control and experimental group was consisted of the inhabitants of the European Union temporarily employed in it, that are officially citizens of countries outside the Union. The research went from March 2012 until March 2015. The reason for that is in the fact that European Union is a union that has many nations, religions, languages etc. Today, in European Union, no language from European Union or from the whole world is predominant. All the member states, nations and languages have pretention to be predominant in European Union, especially world languages such as: English, German and French. Other languages are also in the competition such as: Portuguese, Italian, Spanish etc. This question has not been officially dealt with, and the priority was given to economy, money, profits, market etc., and language has been considered as an easy thing to deal with - by compromise or imposition with the principle "big fish eats the smaller ones". If the Union took that stance towards the language, then logical questions emerge: does every nation in the Union has to know all the languages, would well known linguistic parity and majority principles be respected, or another - new language would be created. If this problem is not addressed in the near future or even now, how will inhabitants of Rome, Paris, Zagreb, Vienna etc. communicate in 20 or 30 years from now? Problem is not based on domination of some of the languages or on strength of states' economy, but solely on the need for communication and understanding between the inhabitants of European Union. There is a question of official language in all meetings of commissions, governing bodies etc. that decide the fate of inhabitants of the European Union. Partially, that is also a problem, whatever the decision would be specific characteristics of particular nation, such as ethnicity, culture or tradition that can be best represented in their mother tongue must not be minimized or disrespected. There are certain dangers hiding in all of that, and one of them is the stance towards local literature, literates and their creativity and other creators of written and verbal art work in their native language. Those are the main reason for conducting this research. In order to get as realistic picture as possible, only youth was included in this research.

\footnotetext{
${ }^{1}$ Correspodence to:

Ahmet Kasumović, PhD, Institute for Human Rehabilitation, Tuzla, B\&H

Phone: 0038761670102

E-mail: ahmetkasumovic@gmail.com
} 
Research was regional in its geographical character, and it has been conducted in areas where significant part of society has business, sports, cultural or any other connections with the current inhabitants of the European Union. The fact is that those young people know only one foreign European/World language (dominantly German and English), and the fact that, today in official communication in European Union, is good amongst smaller group of people, selected, representatives and that should be stimulation to address this question even more, because there are about 600 million people sharing this Union that need good communication. If the U.S.A could select common language (English won over German with just one vote deciding), and U.S.A did this in much more harsh circumstances, but in time, it would be logical for the European Union to do the similar, even if it had to be two or three official languages, so children could start learning those languages in schools as soon as possible. The idea that it is too early for this is wrong because, if countries - members of the European Union wish to function as a union, they have to respect many forms of freedoms such as freedom for workforce to move from one state to another. By that logic every worker would learn only the language of the country he is moving into (France - French, Germany - German, etc.), which will additionally polarize European Union and therefore create more hardships for its inhabitants primarily at their workplace and then in their every day communication. Families that move from one part of European Union to another will face the same problems, especially their children. It will be a bit easier for poly-lingual parts of European Union, but they are not multi-lingual, and we can see the need for uniqueness and togetherness i.e. building a official stance towards the question what language or languages should inhabitants of European Union have to know, and those language(s) will be official administratively and colloquially, and will be obligatory in schools. It should be pointed out that, today, in communication between countries - members of European Union there are over 50 languages in use, and are known mainly just by those who are native speakers of particular language.

\section{METHODOLOGY}

The research was regional in its geographical character. The questionnaire was made and filled only by youth, age spanning from 10 to 30 years. Those were the experimental groups of elementary, high school and university students, as well as passers on the street in cities in Bosnia \& Herzegovina and Kosovo: Pristina, Prizren, Pec, Tuzla, Sarajevo, Mostar, Banja Luka, Travnik and Brcko. There were 1240 respondents in total. Control group was consisted of the same number of respondents that already live and work in the European Union, temporary working abroad, that means their country is not a member of the European Union. Average age of people from the control group was 57 years, and average time spent working in the European Union was 29 years. Countries they are working in are: France (108), Germany (307), Austria (222), England (103), Italy (78), Netherlands (131) and Sweden (201). The questions were not suggestive, but they were pointing towards personal opinion. All the answers were calculated by percentages, cumulatively and were shown graphically or by tables, and they gave reliable results and provided with high-quality discussion on topic: economic issues - cultural issues, today's linguistic state - future linguistic state, as well as futuristic advantages of knowing a certain language and having one common language or languages in the same country - European Union. Every filled questionnaire was individually examined, and all together as well (same or very similar answers and totally different-opposite, and even mutually exclusive answers). All of that was checked with Control group and all of their answers, with all that collected results conclusions were made.

\section{RESULTS}

All respondents stated that European Union needs common language. For only one language in this case English, voted $53 \%$ of the respondents, for two languages - English and German voted $29 \%$ of the respondents, and for three languages - English, German and French voted $18 \%$ of the respondents. For keeping local / native language in communication and literature voted $83 \%$ of the respondents, and only $13 \%$ of the respondents voted for negligence of their native language. As alternative languages Spanish $(52 \%)$ and Italian (48\%) were proposed. These two languages would be learned in schools only as optional subjects. Official language(s) of the European Union should be learned as soon as possible from the earliest age until the end of the high-school as mandatory subjects in each year of school. 


\section{DISCUSSION}

Idea of European unity and cooperation is about 2 centuries old and it began after Prussian - French wars in year 1870. First ideologists were Kalegri the founder of Pan-European movement; Assembly of the League of Nations in Geneva (French minister Briand and German minister Stresman), from year 1923 up until year 1997 (Pfetsch). Inefficient old system of national countries, failed attempts of security and peace in The League of Nations, political, economic, cultural and every other backslide initiated the idea of United European States. Reconstruction after the World War II and European submission to U.S.S.R. and U.S.A. forced European nations to live together, Europe to develop and act (Herz, 1999). Interested in economic cooperation, U.S.A. (even with Marshal's plan) supported European unity from the first day. With foundation of the OECD in 1961, started economic unity of Europe. Plans were developed for democratic Europe, economic market, safety politics, institutional Europe, European identity, common currency, but never for linguistic needs/problems. With contracts signed in Rome, European economic union and European atom union were founded 1st of January 1958. The goal was common market and free flow of goods, capital, services and people, but linguistic issue was never addressed. With all decision-making bodies (council, commissions, European court, parliament), European Union came to existence in year 1967. In city of Mastriht in Netherlands European Union contract was signed (monetary Union and common currency), from 1st of November 1993. None of the agreements, not this one, not contract from Amsterdam (2nd of October 1997), nor contract from Nice (11th of December 2000) addressed issue of language. Science and culture were mentioned, but decisions for unified communication never saw light of the day (Fritzler, 2001). In the same time the science of language have, more or less successfully, proposed new unique communication models: structuralism (Godel, 1957), meta-language, comparative grammar, computer/ machine translation (Locke, Booth, 1955) etc. and in all countries of Europe courses were intensified, mainly courses of English language, then German, French, Italian and Spanish. In local languages, best literal works are still being written; and migrants, dissidents, immigrants and others make unsuccessful attempts to write in learned (foreign) language. Even today, some of these literates are being rewarded, but their work is not much appreciated among the readers (Aleksandar Složnjicin - Switzerland/U.S.A., Salman Rušdi - England, Dževad Karahasan - Austria, Šimo Ešić - Germany, Aleksandar Hemon U.S.A. etc.), as much as they are valued among readers which speak their language natively.

\section{CONCLUSION}

European Union needs common (official) language. It is possible that there are more than one official languages, but not more than three. Considering linguistic principles of parity and majority, official languages of European Union could be: English, German and French, and those languages would be mandatory in all countries - members of European Union from pre-school until the end of the high-school. Alternative (optional) languages could be: Spanish and Italian. In every country - member of European Union, native language would be spoken and used in literature. Work and social life, as largest sources of any language, would profile further linguistic picture of European Union.

\section{REFERENCES}

Pfetsch, F R. (1997). Die Europeaische Union, Geschichte, Institutionen, Prozesse, Minhen.

Godel, R. (1957). Les sources manuscrites du cours de linguistiqegenerale de F. De Saussure (Geneve - Paris)

Herz, D. (1999). Die Europeische Union, Politik, Recht, Wirtschaft, Frankfurt am Main.

Fritzler, M. (2001). Unser Guenter, Die Europeische Union, Bonn.

Locke, W. N. \& Booth, D. A. (2002). Machine Translation of Language, New York. 